Western North American Naturalist 70(2), (C) 2010, pp. 266-269

\title{
RANGE EXPANSION OF THE WESTERN GRAY SQUIRREL (SCIURUS GRISEUS) IN NORTHEASTERN CALIFORNIA
}

\author{
John O. Matson ${ }^{1,4}$, William F. Laudenslayer Jr. ${ }^{2}$, Stephanie A. Trewhitt ${ }^{1}$, and Mary Flores ${ }^{3}$
}

\begin{abstract}
We report the first records of the western gray squirrel (Sciurus griseus) from Modoc County and eastern Lassen County in northeastern California. Specimens from Modoc County represent the first records of the species from the Great Basin geographic province. We conclude that these records represent a range expansion based upon previous fieldwork that did not report the species in the region.
\end{abstract}

Key words: western gray squirrel, Sciurus griseus, range expansion, Great Basin, Warner Mountains.

Mammals of the Great Basin have been the subject of several studies (Grayson 1982, Zeveloff 1988), especially boreal mammals (Brown 1971, 1978; Lawlor 1998 and references therein). To date, few species of tree squirrels are known from the Great Basin. The only species of Sciurus recognized by Zeveloff (1988) as a member of the Great Basin mammalian fauna is Abert's squirrel (Sciurus aberti), which, as he states, "is the only large tree squirrel in the Intermontane West.” Abert's squirrel is known from small, isolated populations confined to higher elevations (above $2000 \mathrm{~m}$ ) in the southeastern portion of the Great Basin (Zeveloff 1988). The western gray squirrel (Sciurus griseus) occurs throughout parts of the Pacific states and Nevada (Hall 1981, Carraway and Verts 1994). In Nevada, S. griseus is known from the eastern slope of the Sierra Nevada (Johnson 1954, Richardson 1954).

Records of $S$. griseus from California are described on the map in Zeiner et al. (1990), which shows western gray squirrels $120 \mathrm{~km}$ farther east than the figure in Hall (1981). Zeiner et al. (1990) did not present specific localities, but they showed the distribution of S. griseus in the Devil's Garden area of Modoc County based on observations by Schneegas and Miller (1961). Schneegas and Miller (1961) also reported sightings as far east as Sugar Hill in the Warner Mountains. Verts and Carraway (1998) reported unverified sightings of western gray squirrels from western Lake County in southern Oregon just north of the Devil's
Garden area in California, making that easternmost locality in Oregon more likely. Records in Hall (1981) from California are those listed by Hall and Kelson (1959). Thus, the 3 northeasternmost localities listed in Hall and Kelson (1959) are the basis for those presented by Carraway and Verts (1994). Neither Hall (1981) nor Carraway and Verts (1994) were aware of the report by Schneegas and Miller (1961). Herein, we report on additional observations of S. griseus from northeastern California that demonstrate this species occurring in the Great Basin. Furthermore, our records substantiate those of Schneegas and Miller (1961) as well as provide habitat information and voucher specimens from the region.

In autumn 2006, we collected 4 S. griseus near Lake City, Surprise Valley, Modoc County, California (Fig. 1). These individuals were prepared as standard skin and skeleton, with heart, liver, lung, and spleen preserved in 95\% ethanol. All specimens were deposited in the Museum of Vertebrate Zoology (MVZ), University of California, Berkeley. Dates and localities are as follows: DOR 5 December 2006, Lake City, County Road 17 and Lake St. (MVZ \#216014); DOR 14 October 2006, Lake City (MVZ \#216017); DOR 20 November 2006, $100 \mathrm{~m}$ North County Roads 17 and 18 (MVZ \#216016); and DOR 16 November 2006, 2.5 miles S Lake City, County Road 17 (MVZ \#216015).

Surprise Valley $\left(41.62^{\circ} \mathrm{N}, 120.15^{\circ} \mathrm{W}\right)$ is on the eastern side of the Warner Mountains.

${ }^{1}$ Department of Biological Sciences, San José State University, San José, CA 95192-0100.

${ }^{2}$ Box 3536, Lake City, CA 96115 .

${ }^{3}$ Warner Mountain Ranger District, Modoc National Forest, Box 220, Cedarville, CA 96104.

4E-mail: johnomatson@gmail.com 


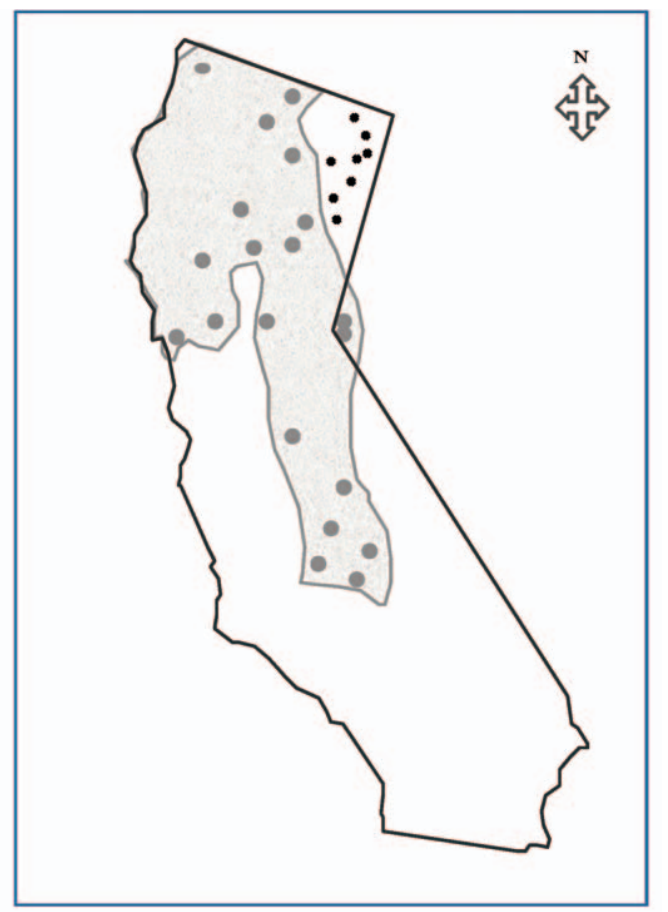

Fig. 1. Distribution of the western gray squirrel (Sciurus griseus) in northern California (redrawn from Hall 1981). Dark dots beyond the shaded region represent observations reported in this study. Those dots from north to south represent Sugar Hill, Lake City, Cedarville, Deep Creek Road, Adin Pass, Jess Valley, Blacks Mountain, and Susanville.

Habitat consists of agricultural fields interspersed with big sagebrush and juniper-sagebrush woodlands (sensu Hickman 1993)—not the typical oak woodland habitat associated with western gray squirrels (Carraway and Verts 1994). Walnut and locust trees are planted in and around Lake City and likely provide a food source. One specimen (MVZ \#216015) contained apples in its stomach. Carraway and Verts (1994) reviewed the literature on dietary habits of western gray squirrels but did not list apples as a food item.

We have observed other S. griseus in Modoc County. From 2006 to 2009, WFL observed western gray squirrels, including 28 dead on the roads, in and about Lake City at elevations of $1490 \mathrm{~m}$ to $1560 \mathrm{~m}$. Individuals seemed more numerous in autumn and winter of 2006/07 than in the other years. Squirrels also appeared to be more numerous in autumn and early winter when the weather cooled, which perhaps concentrated squirrels in areas with walnut and locust trees, which were associated with farmsteads and towns. Modoc County consists largely of western juniper (Juniperus occidentalis) and big sagebrush (Artemisia tridentata) with some wild plum (Prunus subcordata), Jeffrey pine (Pinus jeffreyi), and other trees. A number of squirrels have also been observed in Cedarville by WFL and others, including at least one individual observed several times near the Warner Mountain Ranger District Office in Cedarville.

M. Flores recorded a gray squirrel in the Warner Mountains at Bear Flat, just north of Jess Valley where the road to Soup Creek diverges from the West Warner Road. Cole Estill (rancher in Eagleville) observed 2 western gray squirrels at Patterson in the Warner Mountains.

J.O. Matson (JOM) observed one S. griseus in July 2002 on the east slope of the Warner Mountains about $4.8 \mathrm{~km}$ west of Surprise Valley along Deep Creek Road. In June 2005, JOM saw another on Blue Lake Road between Jess Valley and Blue Lake in the Warner Mountains. Both areas were dominated by ponderosa pine (P. ponderosa). On 2 August 2009, JOM observed another individual at the Merrill Campground (1650 m), Eagle Lake, Lassen County. It was opening a cone of a ponderosa pine and placing the seeds into its cheek pouches.

WFL conducted interviews with several long-term residents of the area to determine whether western gray squirrels have recently colonized the area or whether they always have occurred in the area. John Erquiaga, a local rancher, does not recall western gray squirrels being resident in Lake City 30-40 years ago. Dave Evans, former district silviculturist for the Warner Mountains Ranger District, arrived in Cedarville in 1978 and does not remember seeing squirrels at that time. His first observation was several years later above Deep Creek, and he still remembers that moment. Since then, he has observed other squirrels but rarely in Upper Deep Creek, near Benton Meadows. George Studinski, former wildlife biologist for the Devil's Garden Ranger District, arrived in Alturas in 1974. He says that the only western gray squirrels at that time were around Big Valley and Washington Mountain (Devil's Garden), and he observed none in the Warner Mountains. Randy Hall, a fire ecologist, observed these squirrels in the $1970 \mathrm{~s}$ at the Buck Creek Station, at Lassen Creek, and at Sugar Hill. 
Tom Rickman, Lassen National Forest, observed S. griseus in Susanville, Lassen County, and has observed them at the Blacks Mountain Experimental Forest, north of Poison Lake. Neither Hall (1981) nor Zeiner et al. (1990) show these squirrels as far east as Susanville in Lassen County.

These records and observations demonstrate that western gray squirrels have likely established populations east of Devil's Garden, especially in Surprise Valley of the Great Basin. Occurrence of this large tree squirrel could have been overlooked by early biologists collecting in the area, but it seems unlikely. Field parties from the Bureau of Biological Survey collected in Lake City, Surprise Valley, as early as 1896 and also collected throughout northeastern California (Robert D. Fisher and Neal Woodman, personal communication). Lake City is the type locality for one of the broad-footed moles collected by the Bureau of Biological Survey (Merriam 1897). In 1910, Walter P. Taylor, under the auspices of the Museum of Vertebrate Zoology (MVZ), led a series of collecting trips to document vertebrates in the Warner Mountains (Taylor, MVZ field notes). Their localities included several areas where western gray squirrels are now known, including Sugar Hill. Later, Mailliard (1927) reported on a collection of birds and mammals from various localities in eastern Modoc County. Fieldwork was conducted from 1923 to 1926 and included camps near Eagleville, Deep Creek, Buck Creek, and Jess Valley in the Warner Mountains without recording western gray squirrels.

This paper documents the range expansion of the western gray squirrel eastward from its previously known range in north central California (Hall and Kelson 1959, Hall 1981, Carraway and Verts 1994) to the Great Basin in Surprise Valley, Modoc County, and to near Susanville, Lassen County, California. This range expansion includes the movement of western gray squirrels into a new geographic province, the Great Basin of North America, as defined by Grayson (1993), Russell (1928), and others.

The eastward range expansion of western gray squirrels appears to parallel that of the dusky-footed woodrat (Neotoma fuscipes) in northeastern California (Murray and Barnes 1969). Murray and Barnes suggested the Pit River as a possible corridor used by the woodrat in its eastward route, and we suspect the same for the western gray squirrel. It is possible that the axis of expansion was out of Hat Creek Valley and across the ponderosa pine forests between the Hat Creek Rim and Susanville. The Pit River corridor would provide pine(and/or juniper-) dominated mountain ranges intersected by rather narrow valleys that likely have sage flats. From there, squirrels could move from south of Bieber to the ENE toward Sage Hen (in Modoc and Lassen Counties) and stay in ponderosa pine and/or Jeffrey pine forests. Sage Hen also appears to be connected to the Warner Mountains by higher elevations dominated at least by junipers. Susanville is also connected to the Hat Creek country by bands of mountains. We suspect squirrels could move from the Hat Creek Rim to Susanville without leaving pine forests, though the route would be more circuitous than crossing sagebrush flats.

We thank Robert D. Fisher and Neal Woodman, USGS Patuxent Wildlife Research Center, National Museum of Natural History, who helped find localities in field notes of the Biological Survey. Tom Rickman, Lassen National Forest, provided data on gray squirrels in the Susanville area. Richard Shinn, California Department of Fish and Game, provided copies of the 2 Schneegas and Miller reports, which were very helpful. We thank the kind people of Surprise Valley (Cathy Carlock, Dave Evans, John Erquiaga, Dean Cockrell, Clevon Dixon, Cole Estill, Jean Gorzell, Lee Gorzell, Kathy Hill, Gene Jenson, and Dawn Moore) for providing several important observations on western gray squirrels. Larry Moore and George Studinski also provided information on squirrel presence in Surprise Valley over the past 40 years. We thank Keith Geluso and an anonymous reviewer for their helpful comments and suggestions on an earlier version of this manuscript.

\section{Literature Cited}

BRown, J.H. 1971. Mammals on mountaintops: nonequilibrium insular biogeography. American Naturalist 105:467-478.

1978. The theory of insular biogeography and the distribution of boreal birds and mammals. Great Basin Naturalist Memoirs 2:209-227.

Carraway, L.N., and B.J. VerTs. 1994. Sciurus griseus. Mammalian Species 474:1-7.

Grayson, D.K. 1982. Toward a history of Great Basin mammals during the past 15,000 years. Society of American Anthropological Papers 58:99-126. 
1993. The desert's past: a natural prehistory of the Great Basin. Smithsonian Institution Press, Washington, DC.

HaLL, E.R. 1981. The mammals of North America. 2nd edition. John Wiley \& Sons, New York, NY.

HaLl, E.R., AND K.R. KELSON. 1959. The mammals of North America. Ronald Press Co., New York, NY.

Hickman, J.C., EDITOR. 1993. The Jepson manual: higher plants of California. University of California Press, Berkeley, CA.

Johnson, N.K. 1954. New mammal records for Nevada. Journal of Mammalogy 35:577-578.

LAWLOR, T.E. 1998. Biogeography of Great Basin mammals: paradigm lost? Journal of Mammalogy 79:1111-1130.

Mailliard, J. 1927. The birds and mammals of Modoc County, California. Proceedings of the California Academy of Sciences 16:261-359.

Merriam, C.H. 1897. Two new moles from California and Oregon. Proceedings of the Biological Society of Washington 11:101-102.

Murray, K.F., AND A.M. Barnes. 1969. Distribution and habitat of the woodrat, Neotoma fuscipes, in northeastern California. Journal of Mammalogy 50:43-48.
RichaRDSON, F. 1954. Nevada mammal records. Journal of Mammalogy 35:578-579.

RusselL, R.J. 1928. Basin Range structure and stratigraphy of the Warner range, northeastern California. Bulletin of the Department of Geologic Sciences, University of California Publications 17:387-496.

SchneEgas, E.R., AND C.F. Miller. 1961. Devil's Garden Management Unit: special report on grey squirrels. California Department of Fish and Game, Documents $\# 10851$ and 52.

Verts, B.J., and L.N. Carraway. 1998. Land mammals of Oregon. University of California Press, Berkeley, CA.

Zeiner, D.C., W.F. Laudenslayer Jr., K.E. Mayer, and M. White. 1990. California wildlife. Volume 3, Mammals. State of California, Department of Fish and Game, Sacramento, CA

ZEveloff, S.I. 1988. Mammals of the Intermountain West. University of Utah Press, Salt Lake City, UT.

Received 16 March 2009 Accepted 16 October 2009 